〔総説〕

\title{
ニワトリ受精卵（胚）の体外培養と初期胚操作
}

内 藤 充

農林水産省畜産試験場

茨城県筑波農林研究団地内局私書箱 5 号, 305

\section{Chick Embryo Culture and its Application to Embryo Manipulation}

\author{
Mitsuru Naito \\ National Institute of Animal Industry, \\ Tsukuba Norindanchi P.O.Box 5, Ibaraki 305
}

\section{は じめに}

最近のバイオテクノロジー関係の研究は, 基礎研究が 比較的応用に結びっきやすいこともあり, 極めて盛んに 行われるようになってきた。音産の分野ではこれまで主 として哺乳動物について研究されてきたが, 鳥類である ニワトリについてはその発生学的な特性から, この分野 においてはやや遅れをとっていた感がある。それは, 肧 が多量の卵黄を含み, また, 発生の大半が卵款内で行わ れるため, 体外に取り出して操作をされた胚の発生を正 常に行わせることが困難であったことによる。しかし， 最近になっていくつかの基礎技術の開発が行われ，ニワ トリにおいてあバイオテクノロジー関係の研究が可能と なってきた。本稿では, ニワトリ胚操作研究の基礎技術 となる受精卵 (胚) の培養法と, 最近における胚操作研 究について概説する。

\section{1．ニワトリ受精卵（胚）の初期発生過程}

ニワトリ胚の初期発生については水野（1989）により 詳しく解説されているが，その概要は次のとおりである。 ニワトリの卵巣には 12,000 個以上の卵母細胞が存在して いる。卵母細胞は顆粒層によって取り囲まれ, 卵胞を形 成している。産卵中のニワトリでは, 卵胞は順次栄養物 質である卵黄を蓄積して急速に大きくなる。卵母細胞は 成熟すると細胞核の分裂（減数分裂）が進行し, 第 1 極 体を放出して卵娘細胞となり排卵される。排卵された卵 娘細胞（卵子）は卵管に取り込まれ，卵管漏斗部で排卵
後約15分以内に精子の侵入を受け受精する（Olsen \& Neher, 1948)。ニワトリでは多精子受精となる（Perry， 1987)。排卵されたときには卵子の卵黄膜は内層のみよ りなっているが, 受精後, 連続膜と外層が形成され 3 首 より構成されるようになり, 卵黄膜が完成する。受精後, 卵子は第 2 極体を放出し, 雌性前核を形成する。侵入し た精子はそれぞれ雄性前核を形成し，そのうちの 1 つが 雌性前核之融合して受精は完了する。

最初の細胞の分割は, 排卵後約 4 時間 30 分の, 卵が卵 管峡部にあるときに起こる（Perry，1987）。ニワトリ では盤割となり, 肧盤の中心に狭い溝ができることによ り細胞の分割が行われる。胚は卵が卵管峡部にある間に $4 \sim 8$ 細胞期に達し, 卵管子宮部に入り 4 時間以内に 256細胞期にまで発生が進む。そして, 放卵されるとき には細胞数は約60,000に達する（Spratt \& Haas, 1961a; McMaster \& Modak, 1977; Stepinska \& Olszanska, 1983)。この頃のステージは胚盤葉期とよ ばれ, 肉眼的には中央部の明域と周辺部の暗域とにより 構成されるリングが観察される。無精卵ではこのリング が観察されず全体に白く見える。肧盤の細胞は多層で, 卵黄との間に胚盤下腔とよばれる空間ができる。この後, 胚は胚盤葉上層と胚盤葉下層に分離し, 両者の間に割腔 を形成する（Romanoff, 1960)。放卵は胚盤葉下層が 形成され始める頃に起こり, その後, 原条が形成され, さらに肧盤葉は上中下の三重構造をとり三肧葉が形成さ れる。そして, 胚の形成, 成長の過程を経て, 排卵から 22日目に孵化する。 


\section{2. ニワトリ受精卵（胚）の体外での培養}

ニワトリ受精卵（脹）の体外培養法は，これまで主と して卵款外培養法について研究されてきた（Corner \& Richter, 1973; Auerbach et al., 1974; Dunn, 1974; Dunn \& Boone, 1976, 1977; Dunn \& Fitzharris, 1979; Tuan, 1980; Slavkin et al., 1980; 渡辺と井村, 1983; Rowlett \& Simkiss, 1987, 1989; Rowlett, 1991)。この方法では 3 日間捊卵した 受精卵（肧）をシャーレや台所用ラップなどに移して培 養するもので, 初期の胚発生の観察に用いられてきた。 しかし, 培養の中期以降は明らかな発生の遅延と生存率 の急速な低下が起こり, 舴化させることは不可能であっ た。このことは, これらの卵殼外培養では正常な胚発生 が行われていないことになり, 発生の中期以降の観察に は必ずしも適していないといえる。その理由は大きく2 つ考えられる。1つは呼吸の問題である。胚は発生の 19 日目頃までは漿膜と尿膜の融合した, いわゆる漿尿膜と, そこに分布する毛細血管を通して酸素の取り込みと二酸 化炭素の放出を行う（Rowlett \& Simkiss，1985）。 そして，それ以降，少しずっ肺呼吸に移っていく。しか し，これまで行われてきた卵殼外培養法では漿尿膜の発 達が不十分なため, 呼吸作用が十分に行われないことが 考えられる。むう1つはカルシウムの取り込みの問題で ある。胚が利用するカルシウムは胚の栄養分としての卵 黄や卵白中に含まれているが, これだけでは不十分で, 約 $80 \%$ は卵款のカルシウムを利用することになる（Ro wlett \& Simkiss, 1985)。卵殼のカルシウムの取り込 みもまた漿尿膜を通して行われ，血液を介して肧に運ば れるが, 卵殼外培養法ではカルシウム不足による肧発生 の遅延がみられるようになる。外からカルシウムを補っ ても十分な発育促進効果は得られない（Dunn et al., 1987; 後藤ら，1988）ことから, 卵殼外培養法で粰化さ せることは極めて困難であると考えられる。

最近になって Ono \& Wakasugi（1984）は，2.5日 間邪卵したウズラ受精卵（胚）をニワトリ卵殻内で培養 し粰化させることに成功した。また, Rowlett \& Simkiss（1987）は 3 日間粰卵したニワトリ受精卵（肧） を七面鳥やニワトリ卵款に移して培養することにより䧣 化させることに成功した。この 2 つ成功例ではいずれ あ胚形成が完了したステージから培養を開始したもので あるが, 卵殻を培養器として用いたことにより漿尿膜が 正常に発達し, 呼吸作用や卵殼からのカルシウムの取り 込みが十分に行われた結果, 胚を培養下で躬化させるこ とに成功したものと考えられる。Perry（1988）は分割 の始まっていない 1 細胞期の受精卵（胚）をニワトリの
体内（卵管膨大部）から取り出し, 体外培養法と卵殻を 用いた培養法を組み合わせることにより艀化させること に世界で初めて成功した。これによりニワトリにおいて 1 細胞期からの胚操作が可能になった。また, この方法 は卵管子宮部から取り出した16〜64細胞期のニワトリ受 精卵（肧）の体外培養にも応用できることが示された (Naito \& Perry, 1989)。

最近 Naito et al.(1990b) は餒化率が $7 \%$ と低かっ た Perry（1988）の体外培養法を改良し，1細胞期か らのニワトリ受精卵（胚）の体外での培養で $34.4 \%$ 高 い躬化率を得ることに成功した。この方法の開発により, ニワトリ受精卵（肧）の体外での培養法は実用段階に達 することとなり, 細胞レベルや遺伝子レベルにおける胚 操作研究に応用されている。特に, 肧の操作を正確に行 い，また操作胚を高率に粰化させるためには，この体外 培養法は必須の手法となっている。

\section{3.ニワトリ受精卵（胚）の 1 細胞期 から餒化までの体外での培養法}

ここでは改良されたニワトリ受精卵（肧）の体外での 培養法 (Naito et al., 1990b)について述べる。あら かじめ人工授精しておいた雌ニワトリを, 放卵後 2 時間 45分（排卵後約 2 時間15分）に屠殺し, 卵管膨大部より 濃厚卵白形成途中の未分割の受精卵（胚）を取り出す。 受精卵（肧）の培養法は図 1 に示した 3 つのシステムに より構成される (Pery, 1988; Naito et al., 1990b; Perry \& Mather, 1991)。取り出した受精卵（胚）を 卵黄と卵白が分離しないように注意しながらガラス瓶に 移し, 培養液（水梯性卵白と塩類溶液を $3: 2$ に混合し たもの, Perry, 1988）を入れ, ラップでガラス瓶のロ を密封する。これを $41.5^{\circ} \mathrm{C} て ゙ 24$ 時間静置して培養する。 このとき胚盤が卵黄の真上に位置するようにし，また胚 盤が培養液に沈まないようにする（システム I, Perry, 1988)。通常の産卵後のステージ（胚盤葉期）まで発生 が進んだ段階で受精卵（肧）より濃厚卵白と培養液を除 去し（Naito et al., 1990b）卵黄部分のみを卵款に移 す。そして卵殼に水様性卵白を満たし，卵殼の口をラッ プで密封し, 保定リングで固定する。この状態で, $38^{\circ} \mathrm{C}$, 湿度 $60 \%$ で90度の角度で転卵（15分に 1 回）しながら 3 日間培養する (システムII)。このステージの培養では, 肧が直接空気に接触するのを避ける必要がある。そのた め卵款の鈍端部に形成される気室を残すことにより, 培 養中の水分の減少による内容量の減少分を気室が大きく なって吸収し，空気の侵入を防ぐことができる。これに より胚が空気と直接接触することがなくなり, 正常な胚 

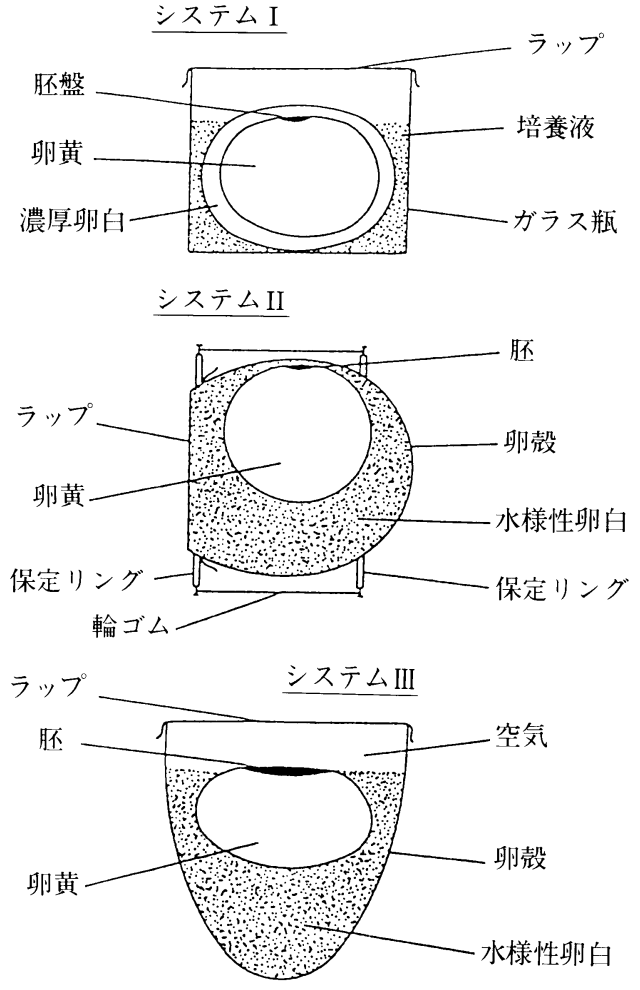

図1。ニワトリ受精卵（肧）の体外培養システム

形成が行われる。Hamburger \& Hamilton (1951) のステージで18に達した頃に，システム IIの卵内容物を ラップにくるんで別の大きな卵款に移す（Rowlett \& Simkiss, 1987)。そして, 卵殸の口をラップで密封し た後， $38^{\circ} \mathrm{C}$, 湿度 $60 \%$ で 30 度の角度で転卵（1 時間に 1 回）しながら14日間培養する（システム III）。その後は 発生座に移し, $37.6^{\circ} \mathrm{C}$, 湿度70\%で, 静置して餒化まで の 4 日間培養する。培養の 21 日目頃より胚は嘴を上に向 け胚呼吸を始めるので，ラップに針で小さな穴をいくつ か開け呼吸を助ける。漿尿膜に分布している血管から血 液がなくなると孵化するので，その少し前にラップを取 り除き，乾燥を防ぐためペトリ皿をかぶせる。培養の 22 日目に粰化する。

上記の方法を用いて32個の受精卵（胚）を処理した結 果, システム I の培養終了後約 $85 \%$ は肧盤葉期への発生 が認められた。生存率は培養の 4 日目 $81.3 \%, 8$ 日目 $65.6 \% ， 15$ 日目 $65.6 \% ， 19$ 日目 $59.4 \% ， 21$ 日目 $40.6 \%$ と なり，睬化率は34.4\%（11羽㲕化）であった。比較のた めにシステム II の培養に移す際に濃厚卵白を除去しない 方法（Perry，1988）を用いて同様に処理したところ， 生存率は培養の 4 日目 $56.8 \% ， 8$ 日目 $37.8 \% ， 15$ 日目 $37.8 \% ， 19$ 日目 $35.1 \% ， 21$ 日目 $21.6 \%$ となり，粰化率は
16.2\%であった。このことは，システム円の培養で濃厚 卵白を除去し水様性卵白と入れ替えることにより, 培養 4 日目の生存率を約 $25 \%$ 高めることができたと同時に, その後の胚の生存性には濃厚卵白除去の影響は全くみら れていないことを示している。システムI の培養を終了 したときの濃厚卵白は非常に柔らかく, また静置した培 養であるためカラザが正常に形成されておらず，濃厚卵 白の付いた状態でシステム II の卵款内に卵内容物を移す と濃厚卵白の一部が壊れて卵黄と分離するすのが多くみ られるようになる。そのため本来ならば比重の関係で卵 黄の真上に位置する肧盤が斜め方向や横方向に向いてし まい，肧盤が培養液に沈んだ状態で培養することになっ てしまう。このような状態では，おそらく呼吸が妨げら れるためと思われるが，正常な肧形成が行われず，発生

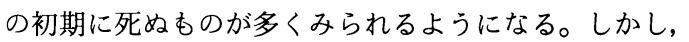
濃厚卵白を除去し卵黄部分のみを卵款に移して水様性卵 白中で培養することにより胚盤は確実に卵黄の真上に位 置するようになり，肧形成が正常に行われるようになっ た。このことが Naito et al. (1990b) の方法を用い ることにより，生存率と粰化率が大幅に向上した大きな 理由と思われる。胚の形成, 成長や粰化にとって濃厚卵 白が必須のものでないことは，産卵後の受精卵（肧）を 用いた培養実験からも同様に確かめられた。この体外培 養法によって艀化した雊は, その後正常に成長し, 通常 のニワトリと全く変わらない繁殖成績を示した（Naito et al., 1990b)。

ニワトリ受精卵（胚）の培養において, 転卵は躬化率 に大きく影響する要因となる。特に沺卵の 4 ～8 日の転 卵は高い孵化率を得るためには必須であると考えられて いる（New，1957; Deeming, 1989)。転卵は漿膜が 卵殼膜と早期に付着するのを防ぎ（New，1957），卵黄 タンパク質の吸収を促進し (Deeming, et al., 1987), 卵殼内における胚の位置を正しく保ち（Robertson, 1961; Lundy，1969），漿尿膜の発達を促進する（Tullett \& Deeming，1987）ことにより卵白（Tullett \& Deeming, 1987; Deeming, 1989) や酸素 (Tazawa, 1980）の吸収，卵殼からのカルシゥムの取り込み （Rowlett \& Simkiss, 1985）を促進するなど多くの 作用を有している。台所用ラップを用いた卵殼外培養に おいてあ転卵を行うことにより胚の発育が明らかに促進 されたことが報告されている（Rowlett and Simkiss， 1987)。このように，一見単純にみえる転卵という操作 は胚の発生にとって極めて重要な作用をしており，1時 間に 1 回程度の転卵を行うことは培養条件下においても 必要である。

卵白は胚の発生に最適な環境を与えると同時に，水分 
とタンパク質の供給源となっている（Freeman，1974）。 特に, オボトランスフェリンやカルシウム結合タンパク 質のような特殊なタンパク質の供給を行っている。また， 細菌が卵殼内に侵入しても卵白中のリゾチームの殺菌作 用により，胚への影響がないように巧みな機構を備えて いる。培養条件下では，これらの作用はすべて水様性卵 白によって行われることになる。

この体外培養法の成功を別の面からとらえると, 濃厚 卵白は胚盤葉期以降の胚の発生と餒化には必須のもので はなく，上に述べた作用はすべて水様性卵白で代用可能 であることを示している。また，培養に用いる水様性卵 白は他のニワトリが産卵したものでよく，卵白を完全に 交換しても, 免疫的な拒絶反応は認められないことが示 された。

\section{4. 細胞レベルにおける胚操作}

ニワトリの産卵後の受精卵（肧）（ステージX; EyalGiladi \& Kochav, 1976) の胚盤葉細胞は多分化能 を有していると考えられ（Eyal-Giladi，1984），容易 に入手でき, 取扱いが簡単であることもあり, 細胞レベ ルでの胚操作には適した材料である。卵黄から分離され た胚盤葉細胞を別の受精卵（肧）の胚盤葉に注入するこ とにより, 細胞レベルの雑種であるキメラを作出するこ とができる。この時, 両者が羽色の異なる品種のものを 用いれば羽毛に現れたキメラ性を容易に識別でき (Marzullo, 1970; Petitte et al., 1990), またニワト リとウズラを用いれば，羽色のみならず，細胞内の核の 形態の違いから細胞レベルで両者を識別することが可能 となる (Le Douarin, 1973)。ニワトリとウズラの肧 盤葉キメラを例にとってその作成法（Naito et al., 1991a）について簡単に触れてみる。まず，ウズラの受 精卵（胚）から胚盤葉を分離する。肧盤葉は 1 枚の薄い 円盤状のものとして卵黄から分離することができる。い くつかの胚盤葉を集めた後, トリプシン処理により細胞 を解離させ, 培養液に胚盤葉細胞を浮遊させる。そして, この細胞浮遊液を先端の外径が50-100 $\mu m$ のマイクロ ピペットに入れ，ニワトリ受精卵（肧）の胚盤葉の中央 付近加ら胚盤下腔に $1 \mu l$ （細胞数約 1,000）程度注入 する。産卵直後のニワトリ受精卵（肧）の胚盤葉は厚さ 約 $30 \mu m$ （Kochav et al., 1980）と極めて薄いため, なるべく表面付近に注入するようにする。注入処理され たニワトリ受精卵（肧）は，前述の体外培養法により発 生を進め, 粰化させる。捊化した㽫がキメラであるかど うかは，外見からは羽毛の色から判定することになる。 羽色に何の変化がなくても羽毛以外の部分でキメラになっ
ている可能性は十分ある (Watanabe et al., 1992)。 その場合には，組織切片の観察などによりキメラである かどうか判定することができる。凍結・融解処理された ウズラ胚盤葉細胞を用いても，同様に羽毛キメラを作製 することができる（Naito et al., 1992）。

ニワトリ受精卵（胚）の胚盤葉へ細胞浮遊液を注入処 理する際, 偶然に将来の胚の軸になる部分を切断するこ とがあり，このような場合，双子あるいは三つ子の胚が 生じる（Spratt \& Haas, 1960, 1961a, b; Slack, 1983)。これらの肧は通常 1 週間以内に発生中止となる が, 艀化直前まで発生が進んだ双子の胚が観察されてい る (Naito et al., 1991c)。もし, これらの胚が粰化 すれば一卵性の双子となるが，稱化の可能性については 明らかではない。

ニワトリとウズラでは分類学上の属が異なり, キメラ にした場合, 免疫的な拒絶反応が起こることが考えられ る。実際, 脊䯣移植によって作成したニワトリとウズラ のキメラでは, 明らかな拒絶反応が起きることが報告さ れている (Kinutaini \& Le Douarin, 1985; Kinutani et al., 1986, 1989)。しかし，脊䯣之同時に 胸腺も移植した場合には免疫寛容が得られたことから， 自己と非自己の認識には胸腺が重要な役割を果たしてい ると考えられている（Ohki et al., 1987，1988）。胚盤 葉キメラの場合は脊䯣キメラより早いステージで処理さ れており，自己と非自己の認識ができる以前である可能 性が高く，また非常に多くの種類の細胞を注入している ことから, 免疫寛容が得られる可能性がある。

キメラは異種細胞の集合体であり, 個々の細胞はもと の品種なり系統なりに由来したものである。したがって キメラから得られる子孫はもとの品種なり系統，あるい はそれらの雑種が得られることになる。しかし，実際に は肧盤葉キメラで生殖系列がキメラになる率は $1 \%$ 前後 と極めて低いのが実状である（Petitte et al. 1990; 大塚ら，1991）。肧盤葉細胞の注入では，ホストの肧の 発生ステージや注入部位により, ドナー細胞の分布位置 に限局がみられる（Watanabe et al., 1992）が， あ る特定の組織なり器官なりを確実に高い割合でキメラに することは容易ではない。もし，胚盤葉細胞の注入で高 率に生殖系列をキメラにできる方法が開発されれば，胚 盤葉キメラの用途は大きく広がるであろう。

ニワトリの生殖細胞は, 胚の始原生殖細胞が起源となっ て形成される。始原生殖細胞は胚盤葉上層の中央付近が 起源 (Eyal-Giladi et al., 1981; Ginsburg \& EyalGiladi, 1987) で, 発生に伴い肧盤葉下層に移動し, 肧発生の初期の原始線条期に将来の胚の前方および前側 方の明域と暗域にあたる生殖弦に現れる（Swift，1914; 
Fujimoto et al., 1976b; Ginsburg \& Eyal-giladi, 1986)。その後, 発生の進行とともに, 主に血管系を通 じて運ばれ, 肧内の生殖巣原基へ移住する（Singh \& Meyer, 1967; Swartz \& Domm, 1972)。始原生殖 細胞は体細胞と比べ, 細胞がやや大きく（直径 15-20 $\mu m$ ), 核が大きくて（直径 8 $-10 \mu m$ ), 片寄っており, またグリコーゲンを多量に含むなどの特徵がある (Fujimoto et al., 1976a)。さらに細胞自身がアメー バ状の運動をし, 何らかの化学物質に向かって移動する 性質を有しており, この走化性が始原生殖細胞の生殖巣 原基への移住と関係しているのではないかと考えられて いる (Kuwana \& Fujimoto, 1984; Kuwana et al., 1986, 1987)。始原生殖細胞を取り出し, これを別の胚 に移植することができれば生殖細胞を確実に操作できる ようになる。生殖弦あるいは血流中に現れた始原生殖細 胞を別の胚の生殖弦の部分あるいは血管中に注入処理し たところ，生殖系列に取り込まれたことが報告されてい る (Simkiss et al., 1989, 1990; Simkiss, 1991)。 そして, この方法で移植処理した胚を孵化させ, その個 体から後代をとり, 移植された始原生殖細胞由来の個体 が得られるかどうかを調べた結果, 成功例はウズラと七 面鳥のみで，ニワトリでは現在のところ成功例は報告さ れていない (Reynaud, 1976; Shuman \& Shoffner, 1982; Wentworth et al., 1989; Petitte et al., 1991)。この方法は, 始原生殖細胞の集め方や胚への注 入方法などの改良の余地はあるものの, 生殖細胞を確実 に操作できるという点で，今後注目を集めることとなる であろう。

最近, 核移植によるクローン動物の作出 (McGrath \& Solter, 1983; Willadsen, 1986; Prather et al., 1987）が話題となっているが，ニワトリにおいては今の ところ明らかな成功例は報告されていない。クローンニ ワトリができれば, 育種分野だけでなく栄養学や生理学 などの他の研究分野においても実験用動物としての用途 が広がり, 学問的に新たな進展が期待される。クローン ニワトリの作出法として将来的に有望なのは E S 細胞 （胚性幹細胞）（Evans \& Kaufman, 1981; Martin, 1981; Axelrod, 1984; Robertson, 1986）を用いる方 法である。 E S 細胞とは, 肧発生の初期の時点で分化が 足踏み状態にある多分化能を有する継代可能な細胞であ る。 E S 細胞は今のところマウスなど一部の動物でしか 樹立されていないのが現状である (Wilmut et al., 1991)。むし，ニワトリで $\mathrm{E} \mathrm{S}$ 細胞が樹立できれば，シャー レの中で培養されている細胞から核を取り出し，これを 除核した受精卵（肧）に移植することにより，培養細胞 由来の個体を多数作出できることになる。しかし，その
ためにはニワトリで $\mathrm{E} \mathrm{S}$ 細胞を樹立することが必須条件 であり, さらに核移植法の開発など, 多くの技術開発が 必要である。

\section{5．形質転換ニワトリの作製技術}

交配によらないで遺伝子を導入することができれば, 選抜と交配を繰り返す現在のニワトリの育種法に新たな 手法を導入できることになる（Bulfield，1985; Freeman \& Messer, 1985; Freeman \& Bumstead, 1987b; Shuman, 1990)。これまでニワトリへの外来遺 伝子の導入法としていくつかの方法が試みられてきた。 それは次のような方法である。

（1）レトロウイルスベクター法：レトロウイルスは遺 伝子として RNA をあち, 自身の逆転写酵素により DNA を合成する。このウイルス DNAは, 宿主の細 胞の DNA に組み込まれる性質を有している (Freeman \& Bumstead, 1987b)。レトロウイルスのこのような 性質を利用して, あらかじめ外来遺伝子を組み込んだレ トロウイルスをニワトリ受精卵（胚）に感染させ, 躬化 させると，モザイク状ではあるが，外来遺伝子をもつ二 ワトリ，すなわち形質転換ニワトリが作出される (Souza et al., 1984; Shuman \& Shoffner, 1986; Salter et al., 1986, 1987; Hughes et al., 1986; Hippenmeyer et al., 1988; Bosselman et al., 1989a,b, 1990a,b; Crittenden et al., 1989; Salter \& Crittenden, 1989; Crittenden \& Salter, 1988, 1990a,b; Chen et al., 1990)。この方法で生殖系列に も外来遺伝子を導入できることが証明されており，ニワ トリのように前核に遺伝子を直接注入することが困難な 動物種における外来遺伝子導入法として注目されている。 特に, この方法では遺伝子 1 コピーを染色体に組み込め ることに特色がある。この方法の難点は, レトロウイル スの感染によりニワトリ自身に影響がでる恐れのあるこ と，サイズの大きな遺伝子を導入することができないこ となどである (Freeman \& Bumstead, 1987b)。

（2）肧盤葉細胞の移植による方法: これは, 卵黄加ら 分離した胚盤葉細胞にトランスフェクションなどにより 遺伝子を導入し，この細胞を別の受精卵（胚）の肧盤葉 に注入し，キメラ個体を作出し，その後代をとって形質 転換ニワトリを作出しようとする方法である（Gibbins et al., 1990; Brazolot et al., 1991)。細胞への遺伝 子導入法としては, リン酸カルシウム法, DEAE-デ キストラン法, リポフェクション法, エレクトロポーレー ション法などがあるが, 導入効率はいずれも数\%程度で, さらに染色体への組み込みはその約 $1 / 10$ の効率になる 
と考えられる。胚盤葉細胞の移植による方法は, 産卵後 の受精卵 (胚) を扱うという点では, 実験操作を行いや すいが，胚盤葉細胞への遺伝子の導入効率が低い（4\%， Gibbins et al., 1990; Brazolot et al., 1991) こと, 前述したように, 注入された細胞が生殖系列に取り込ま れる率が低いことなどから, 現時点では改良すべき点を 多く残している。しかし，E S 細胞が樹立されれば新た な進展が期待される方法である。

（3）始原生殖細胞の移植による方法 : 発生に伴い生殖 細胞に分化する始原生殖細胞に遺伝子を導入し，これを 胚に注入して生殖細胞に外来遺伝子を取り込ませる方法 で，確実に生殖細胞に遺伝子を導入できる利点がある。 レトロウイルスを用いて始原生殖細胞に外来遺伝子を導 入し，これを別の胚に移植して生殖系列キメラを作製し， その後代をとって形質転換ニワトリを作出しようとする 試みも行われている（Simkiss et al., 1990)。しかし, 注入処理された胚はそれ自身の生殖細胞をもっているた め, 注入した始原生殖細胞由来の個体をいかに効率よく 生産するかが今後の検討課題である（Aige-Gil \& Simkiss, 1991; Hallett \& Wentworth, 1991)。

(4) マイクロインジェクション法 : ニワトリ肧の体外 培養法の開発により可能になった方法で，未分割の受精 卵（胚）をニワトリの卵管膨大部から取り出し，胚盤の 細胞質に直接遺伝子を注入し, 培養によって殍化させ, 形質転換ニワトリを作出する方法である。ニワトリの場 合, 細胞質が不透明なため, マウスなどのように前核に 直接遺伝子を注入することができない。しかし，マウス で示されているように, 前核注入に比べ細胞質注入の場 合の遺伝子の導入効率は約10分の 1 となるものの, 遺伝 子導入は可能である（Brinster et al., 1985）ことか ら, ニワトリにおいてもこの方法が応用されている。こ の方法を用いた結果, モザイク状ではあるあのの, 外来 遺伝子の肧への導入と発現には成功している（Sang \& Perry, 1989; Perry \& Sang, 1990; Naito et al., 1990a, 1991b; Perry et al., 1991) ものの, 染色体へ の組み込みについては明らかにされていない。

（5）精子をべクターとする方法 : 精子は受精の過程で 確実に卵子の中に取り込まれ，雄性前核を形成し，卵子 由来の雌性前核と融合することから, 精子をべクターと することにより外来遺伝子の導入をはかることが可能で あると考えられる。遺伝子は精子表面に付着しやすい性 質があり，これを利用して外来遺伝子を付着させた精子 を人工授精することにより，遺伝子導入が試みられた。 遺伝子はいったんは受精卵（胚）に取り込まれるようで あるが，残念ながら染色体には組み込まれることなく， 肧発生の過程で消失してしまうことが報告されている
(Freeman \& Bumstead, 1987b)。一方では, 特殊な 培養液を用いることにより，この方法で遺伝子の導入に 成功し, 子孫へも外来遺伝子が伝達されたとの報告（G ruenbaum et al., 1991) があり, マウスやブタでの 例 (Lavitrano et al., 1989; Gandolfi et al., 1989）と同様, 論議の的となっているところであるが, これらのデータを明らかに否定する報告む出されている (Brinster et al., 1989; Gavora et al., 1991)。また, 精子を用いる遺伝子導入法として, 偽受精による方法が 報告されている（Pandey \& Patchell, 1982)。これ はガンマー線などで精子の DNAを分断した後, 卵子 と受精させ, その後正常な精子で再度受精させることに より, 先に受精した精子の DNA の一部が, その後の 正常な受精の過程で染色体に取り込まれることによるも のとされている。この方法により, 卵款色の遺伝子 (Pandey \& Patchell, 1982; Tomita et al., 1988), 羽毛の遺伝子 (Baumgartner et al., 1986), マーカー 遺伝子（Bumstead et al., 1987a,b）の導入に成功し たとの報告かある。しかし，一方ではこれらの結果を否 定する報告（Shoffner et al., 1990）あ出されている。 もしこの方法で遺伝子導入が可能であるとしてあ, 目的 とする遺伝子のみを導入することは不可能であるため, 実用化される見通しは乏しいものと思われる。

すべての細胞は同じセットの遺伝子をあっているにも かかわらず，個々の遺伝子は巧みな制御のもとにおいて， 特定の組織で, 特定の時期に発現するよう調節されてお り，これによって個体としての統制がはかられている。 形質転換マウスで示されているように，たとえ外来遺伝 子を導入できたとしても発現の時期特異性や組織特異性 を制御できないため, 外来遺伝子が生涯を通じて発現し ており, 育種的観点からは現在のところあまり利用性が 期待できないのが実状である。したがって, 今後は遺伝 子導入法の開発と同時に, 遺伝子発現の制御が可能とな るような方法を開発することが, 形質転換ニワトリを育 種に応用する場合の必須条件となるであろう。

さらに重要なことは, どんな遺伝子を操作するかとい う問題である。ニワトリの重要な経済形質はほとんどが 多くの遺伝子によってコントロールされる量的形質であ ることを考えると, 単に外来遺伝子の導入というだけで は育種へ応用することは困難である。また，ニワトリに おける遺伝子地図の作成がほとんよ゙進んでおらず，明ら かな主働遺伝子のみがそのリンケージマップとして示さ れている程度である (Somes, 1978; Bitgood \& Somes, 1990)。これらのことから, アメリカでニワト リの遺伝子地図を作成するプロジェクトが計画されてい る(Crittenden, 1991)。 
遺伝子レベルでニワトリの胚を操作する研究はまだ始 まったばかりであり, その基礎となる情報が明らかに不 足している状態である。しかし, 最近の分子生物学の進 歩はめざましく, 近い将来, 通常の選抜過程では考慮し にくい抗病性（Freeman \& Bumstead, 1987a）など についてその応用がはかられるようになることが予想さ れる。また，ニワトリを用いて，医薬品などの有用物質 を例えば卵の中に生産することが可能となるかもしれな い。

\section{おわりに}

以上, ニワトリ受精卵 (肧) の体外培養と胚操作研究 について簡単に述べてきた。ニワトリにおいては体外培 養法の開発により, 卵管から取り出した未分割の受精卵 （胚）を卯卵器の中で個体にまで発生を進めさせること が可能となった。これは, 哺乳動物の胚操作において, 操作胚を必ず子宮に移植しなければ個体にまで発生を進 めさせることができない点に比べ，大きなメリットとな る。これによって, 発生のあらゆるステージの肧操作が 可能となり, また, 操作胚を高率に梛化させることがで きるようになった。このことからすれば, ニワトリは肧 操作研究に適した実験材料であると考えられる。ニワト リ胚はその大半が体外発生のため, 古くから発生学の実 験材料として広く用いられてきており，1細胞期からの 肧操作が可能となったことを考えると，新しい動物実験 系の開発の面からむその重要性は今後ますます大きくな ることが予想される。

\section{文 献}

Aige-Gil, V. \& K. Simkiss, 1991. Sterilising embryos for transgenic chimaeras. Brit. Poult. Sci., 32: 427-438.

Auerbach, R., L. Kubai, D. Knighton \& J. Folkman, 1974. A simple procedure for the long-term cultivaion of chicken embryos. Dev. Biol., 41: 391-394.

Axelrod, H.R., 1984. Embryonic stem cell lines derived from blastocysts by a simplified technique. Dev. Biol., 101: 225-228.

Baumgartner, J., I.E. Ezzat \& Z. Koncekva, 1986. An attempt at genetic transformation in chickens through cock sperm irradiation. Theor. Appl. Genet., 72: 264-268.

Bitgood, J.J. \& R.G. Somes, Jr., 1990. Linkage relationships and gene mapping. in: Poultry Breeding and Genetics. Ed. R.D. Crawford, pp. 469-495. Elsevier, New York.

Bosselman, R.A., R.-Y. Hsu, T. Boggs, S. Hu, J. Bruszewski, S. Ou, L. Kozar, F. Martin, C. Green, F. Jacobsen, M. Nicolson, J.A. Schultz, K.M. Semon, W. Rishell \& R.G. Stewart, 1989b. Germline transmission of exogenous genes in the chicken. Science, 243: $533-535$

Bosselman, R.A., R.-Y. Hsu, T. Boggs, S. Hu, J. Bruszewski, S. Ou, L. Souza, L. Kozar, F. Martin, M. Nicolson, W. Rishell, J.A. Schultz, K.M.Semon \& R.G.Stewart, 1989a. Replication-defective vectors of reticuloendotheliosis virus transduce exogenous genes into somatic stem cells of the unincubated chicken embryo. J. Virol., 63: 2680-2689.

Bosselman, R.A., R.-Y. Hsu, T. Boggs, S. Hu, M. Nicolson \& M.J. Briskin, 1990a. Insertion and expression of model genes in the chicken germline. Proc. 4th World Cong. Genet. Appl. Livestock Prod. (Edinburgh), XVI: 94-96.

Bosselman, R.A., R.-Y. Hsu, M.J. Briskin, T. Boggs, S. Hu, M. Nicolson, L. M. Souza, J.A. Schultz, W. Rishell \& R.G. Stewart, 1990b. Transmission of exogenous genes into the chicken. J. Reprod. Fert., Suppl. 41: 183-195.

Brazolot, C.L., J.N. Petitte, R.J. Etches \& A.M.V. Gibbins, 1991. Efficient transfection of chicken cells by lipofection, and introduction of transfected blastodermal cells into the embryo. Mol. Reprod. Dev., 30 : 304-312.

Brinster, R.L., H.Y. Chen, M.E. Trumbauer, M.K. Yagle \& R.D. Palmiter, 1985. Factors affecting the efficiency of introducing foreign DNA into mice by microinjecting eggs. Proc. Natl. Acad. Sci. USA, 82: 4438-4442.

Brinster, R.L., E.P. Sandgren, R.R. Behringer \& R.D. Palmiter, 1989. No simple solution for making transgenic mice. Cell, 59: 239-241.

Bulfield, G., 1985. The potential for improvement of commertial poultry by genetic engineering techniques. in: Poultry Genetics 
and Breeding. Ed. W. G. Hill, J.M. Manson \& D. Hewitt, pp. 37-46. Longman group, Harlow.

Bumstead, N., B.M. Freeman, A.C.C. Manning \& K. Howes, 1987b. Genetic transformation of chickens using irradiated sperm: Cotransfer of undesirable genes. Avian Pathol., 16: 417-424.

Bumstead, N., L.I. Messer, B.M. Freeman \& A.C.C. Manning 1987a. Genetic transformation of chickens using irradiated male gametes. Heredity, 58: 25-30.

Chen, H.Y., E.A. Garber, E. Mills, J. Smith, J.J. Kopchick, A.G. DiLella \& R.G. Smith, 1990. Vectors, promoters, and expression of genes in chick embryos. J. Reprod. Fert., Suppl. 41: 173-182.

Corner, M.A. \& A.Ph.J. Richter, 1973. Extended survival of the chick embryo in vitro. Experientia, 29: 467-468.

Crittenden, L.B., 1991. USDA ARS-Michigan State University chicken genome mapping project. MAGazine, 1: 6-7.

Crittenden, L.B. \& D.W. Salter, 1988. Insertion of retroviruses into the avian germ line. Proc. 2nd Int. Conf. Quant. Genet. (Sunderland), pp. 207-214.

Crittenden, L.B. \& D.W. Salter, 1990a. Expression of retroviral genes in transgenic chickens.

J. Reprod. Fert., Suppl. 41: 163-171.

Crittenden, L.B. \& D.W. Salter, 1990b. Transgenic chickens resistant to avian leukosis virus. Proc. 4th World Cong. Genet. Appl. Livestock Prod. (Edinburgh), XVI: 453-456.

Crittenden, L.B., D.W. Salter \& M.J. Federspiel, 1989. Segregation, viral phenotype, and proviral structure of 23 avian leukosis virus inserts in the germ line of chickens. Thoer. Appl. Genet., 77: 505-515.

Deeming, D.C., 1989. Characteristics of unturned eggs: critical period, retarded embryonic growth and poor albumen utilisation. Brit. Poult. Sci., 30: 239-249.

Deeming, D.C., K. Rowlett \& K. Simkiss, 1987. Physical influences on embryo development. J. Exp. Zool., Suppl. 1: 341-345.
Dunn, B.E., 1974. Technique for shell-less culture of the 72-hour avian embryo. Poult. Sci., 53: 409-412.

Dunn, B.E. \& M.A. Boone, 1976. Growth of the chick embryos in vitro. Poult. Sci., 55: 1067-1071.

Dunn, B.E. \& M.A. Boone, 1977. Growth and mineral content of cultured chick embryos. Poult. Sci., 56: 662-672.

Dunn, B.E., N.B. Clark \& K.E. Scharf, 1987. Effect of calcium supplementation on growth of shell-less cultured chick embryos. J. Exp. Zool., Suppl. 1: 33-37.

Dunn, B.E., T.P. Fitzharris, 1979. Differentiation of the chorionic epithelium of chick embryos maintained in shell-less culture. Dev. Biol., 71: 216-227.

Evans, M.J. \& M.H. Kaufman, 1981. Establishment in culture of pluripotential cells from mouse embryos. Nature, 292: 154-156.

Eyal-Giladi, H., 1984. The gradual establishment of cell commitments during the early stages of the chick development. Cell Differ., 14: 245-255.

Eyal-Giladi, H., M. Ginsburg \& M. Farbarov, 1981. Avian primordial germ cells are of epiblastic origin. J. Embryol. exp. Morph., 65: $139-147$.

Eyal-Giladi, H. \& S. Kochav, 1976. From cleavage to primitive streak formation: A complementary normal table and a new look at the first stages of development of the chick. I. General morphology. Dev. Biol., 49: 321-337.

Freeman, B.M., 1974. Development of the Avian Embryo. Chapman and Hall, London.

Freeman, B.M. \& N. Bumstead, 1987a. Breeding for disease resistance-The perspective role of genetic manipulation. Avian Pathology, 16: 353-365.

Freeman, B.M. \& N. Bumstead, 1987b. Transgenic poultry: Theorey and practice. World's Poult. Sci. J., 43: 180-189.

Freeman, B.M. \& L.I. Messer, 1985. Genetic manipulation of the domestic fowl-a review. World's Poult. Sci. J., 41: 124-132. 
Fujimoto, T., T. Ninomiya \& A. Ukesima, 1976a. Observations of the primordial germ cells in blood samples from the chick embryo. Dev. Biol., 49: 278-282.

Fujimoto, T., A. Ukeshima \& R. Kiyofuji, 1976b. The origin, migration and morphology of the primodial germ cells in the chick embryo. Anat. Rec., 185: 139-154.

Gandolfi, F., M. Lavitrano, A. Camaioni, C. Spadfora, G. Siracusa \& A. Lauria, 1989. The use of sperm-mediated gene transger for the generation of transgenic pigs. J. Reprod. Fert. Abstr. Series No. 4: 10.

Gavora, J.S., B. Benkel, H. Sasada, W.J. Cantwell, P. Fiser, R.M. Teather, J. Nagai \& M.P. Sabour, 1991. An attempt at spermmediated gene transfer in mice and chickens. Can J. Anim. Sci., 71: 287-291.

Gibbins, A.M.V., C.L. Brazolot, J.N. Petitte, G. Liu \& R.J. Etches, 1990. Efficient transfection of chicken blastodermal cells and their incorporation into recipient embryos to produce chimeric chicks. Proc. 4th World Cong. Genet. Appl. Livestock Prod. (Edinburgh), XVI: 119-122.

Ginsburg, M. \& H. Eyal-Giladi, 1986. Temporal and spatial aspects of gradual migration of primordial germ cells from the epiblast into the germinal crescent in the avian embryo. J. Embryol. exp. Morph., 95: 53-71.

Ginsburg, M. \& H. Eyal-Giladi, 1987. Primordial germ cells of the young chick blastoderm originate from the central zone of the area pellucida irrespective of the embryo-forming process. Development, 101: 209-219.

後藤和文・高橋陽子・中西喜彦・小川清彦，1988．鶏受 精卵の卵殼外発生. 家禽会誌，25: 27-33.

Gruenbaum, Y., E. Revel, S. Yarus \& A. Fainsod, 1991. Sperm cells as vectors for the generation of transgenic chickens. J. Cell. Biochem., Suppl. 15E: 194.

Hallett, J.S. \& B.C. Wentworth, 1991. The effects of busulfan on gonadal differentiation and development in Japanese quail (Coturnix coturnix japonica). Poult. Sci., 70: 1619-1623.

Hamburger, V. \& H.L. Hamiiton, 1951. A series of normal stages in the development of the chick embryo. J. Morphol., 88: 49-92.

Hippenmeyer, P.J., G.G. Krivi \& M.K. Highkin, 1988. Transfer and expression of the bacterial NPT-II gene in chicken embryos using a Schmidt-Ruppin retrovirus vector. Nucleic Acids Res., 16: 7619-7631.

Hughes, S.H., E. Kosik, A.M. Fadly, D.W. Salter \& L.B. Crittenden, 1986. Design of retroviral vectors for the insertion of foreign deoxyribonucleic acid sequences into the avian germ line. Poult. Sci., 65: 1459-1467.

Kinutani, M., M. Coltey \& N.M. Le Douarin, 1986. Postnatal developmdent of demyelinating disease in avian spinal cord chimeras. Cell, 45: 307-314.

Kinutani, M., N.M. Le Douarin, 1985. Avian spinal cord chimeras. 1. Hatching ability and post hatching survival in homo- and heterospecific chimeras. Dev. Biol., 111: 243255.

Kinutani, M., K. Tan, J. Desaki, M. Coltey, K. Kitaoka, Y. Nagano, Y. Takashima \& N.M. Le Douarin, 1989. Avian spinal cord chimeras. Further studies on the neurological syndrome affecting the chimeras after brith. Cell Differ. Dev., 26: 145-162.

Kochav, S., M. Ginsburg \& H. Eyal-Giladi, 1980. From cleavage to primitive streak formation: A complementary normal table and a new look at the first stages of the developmant of the chick. II. Microscopic anatomy and cell population dynamics. De v. Biol., 79: 296-308.

Kuwana, T \& T. Fujimoto, 1984. Locomotion and scanning electron microscopic observations of primordial germ cells from the embryonic chick blood in vitro. Anat. Rec., 209: 337-343.

Kuwana, T., H. Maeda-Suga \& T. Fujimoto, 1986. Attraction of chick primordial germ cells by gonadal anlage in vitro. Anat. Rec., 215: 403-406.

Kuwana, T., Y. Miyayama, Y. Kajiwara \& T. Fujimoto, 1987. Behavior of chick primordial germ cells moving toward gonadal primor- 
dium in vitro: Scanning electrom microscopic study. Anat. Rec., 219: 164-170.

Lavitrano, M., A. Camioni, V.M. Fazio, S. Dolic, M.G. Farace \& C. Spadafora, 1989. Sperm cells as vectors for introducing foreign DNA into eggs. Genetic transformatoin of mice. Cell, 57: 717-723.

Le Douarin, N.M., 1973. A biological cell labeling technique and its use in experimental embryology. Dev. Biol., 30: 217-222.

Lundy, H., 1969. A review of the effects of temperature, humidity, turning and gaseous environment in the incubator on the hatchability of the hen's egg. in: The Fertility and Hatchability of the Hen's Egg. Ed. T.C. Carter \& B.M. Freeman. pp. 143-176. Oliver \& Boyd, Edinburgh.

Martin, G., 1981. Isolation of a pluripotent cell line from early mouse embryos cultured in medium conditioned by teratocarcinoma stem cells. Proc. Natl. Acad. Sci. USA, 78: 7634-7638.

Marzullo, G., 1970. Production of chick chimaeras. Nature, 225: 72-73.

McGrath, J. \& D. Solter, 1983. Nuclear transplantation in the mouse embryo by microsurgery and cell fusion. Science, 220: 1300-1302.

McMaster, G. \& S.P. Modak, 1977. Cellular and biochemical parameters of growth of chick blastoderms during early morphogenesis. Differentiation, 8: 145-152.

水野丈夫, 1989. 鳥類. 「脊椎動物の発生」上, 岡田節 人編, pp. 391-424, 培風館, 東京.

Naito M., K. Agata, K. Otsuka, K. Kino, M. Ohta, K. Hirose, G. Eguchi, M. Watanabe, M. Kinutani, K. Nirasawa \& T. Oishi, 1990a. Culture of the chick embryo and manipulation of the early avian embryo. Proc. 4th World Cong. Genet. Appl. Livestock Prod. (Edinburgh), XVI: 135-138.

Naito, M., K. Agata, K. Otsuka, K. Kino, M. Ohta, K. Hirose, M.M. Perry \& G. Eguchi, 1991b. Embryonic expression of $\beta$-actinlacZ hybrid gene injected into the fertilized ovum of the domestic fowl. Int. J.Dev. Biol.,
35: $69-75$.

Naito, M., K. Nirasawa \& T. Oishi, 1990b. Development in culture of the chick embryo from fertilized ovum to hatching. J. Exp. Zool., 254: 322-326.

Naito M., K. Nirasawa \& T. Oishi, 1992. Preservation of quail blastoderm cells in liquid nitrogen. Brit. Poult. Sci., 33: in press.

Naito M. \& M.M. Perry, 1989. Development in culture of the chick embryo from cleavage to hatch. Brit. Poult. Sci., 30: 251-256.

Naito M., M. Watanabe, M. Kinutani, K. Nirasawa \& T. Oishi, 1991a. Production of quail-chick chimaeras by blastoderm cell transfer. Brit. Poult. Sci. 32: 79-86.

Naito M., M. Watanabe, K. Nirasawa \& T. Oishi, 1991c. Developmental ability of twin embryos produced by microinjection treatment into chick blastoderm. Poult. Sci., 70: 1261-1264.

New, D.A.T., 1957. A critical period for the turning of hen's egg. J. Embryol. exp. Morphol., 5: 293-299.

Ohki, H., C. Martin, M. Coltey \& N.M. Le Douarin, 1988. Implants of quail thymic epithelium generate permanent tolerance in embryonically constructed quail/chick chimeras. Development, 104: 619-630.

Ohki, H., C. Martin, C. Corbel, M. Coltey \& N.M. Le Douarin, 1987. Tolerance induced by thymic epithelial grafts in birds. Science, 237: 1032-1035.

Olsen, N.W. \& B.H. Neher, 1948. The site of fertilization in the domestic fowl. J. Exp. Zool., 109: 355-366.

Ono, T. \& N. Wakasugi, 1984. Mineral content of quail embryos cultured in mineral-rich and mineral-free condititons. Poult. Sci.,63: 159-166.

大塚勝正 - 木野勝敏 - 本田元好 - 餅井真 - 阿形清和 - 江 口吾朗, 1991. ニワトリキメラの作成, 細胞工学, 10: 513-518.

Pandey, K.K. \& M.R. Patchell, 1982. Genetic transformation in chickens by the use of irradiated male gametes. Mol. Gen. Genet., 
186: $305-308$.

Perry, M.M., 1987. Nuclear events from fertilisation to the early cleavage stages in the domestic fowl (Gallus domesticus). J. Anat., 150: 99-109.

Perry, M.M., 1988. A complete culture system for the chick embryo. Nature, 331: 70-72.

Perry, M.M. \& C.M. Mather, 1991. Satisfying the needs of the chick embryo in culture, with emphasis on the first week of development. in: Avian Incubation. Ed. S.G. Tullett, pp. 91-106, Butterworth-Heinemann, London.

Perry, M., D. Morris, S. Hettle \& H. Sang, 1991. Expression of exogenous DNA during the early development of the chick embryo. Roux's Arch. Dev. Biol., in press.

Perry, M.M. \& H.M. Sang, 1990. In vitro culture and approaches for DNA transfer in the chick embryo. Proc. 4th World Cong. Genet. Appl. Livestock Prod. (Edinburgh), XVI: 115-118.

Petitte, J.N., M.E. Clark \& R.J. Etches, 1991. Assessment of functional gametes in chickens after transfer of primordial germ cells. J. Repord. Fert., 92: 225-229.

Petitte, J.N., M.E. Clark, G. Liu, A.M.V. Gibbins \& R.J. Etches, 1990. Production of somatic and germline chimeras in the chickens by transfer of early blastodermal cells. Developmant., 108: 185-189.

Prather, R.S., F.L. Barnes, M.M. Sims, J.M. Robl, W.H. Eyestone \& N.L. First, 1987. Nuclear transplantation in the bovine embryo: Assessment of donor nuclei and recipient oocyte. Biol. Reprod., 37: 859-866.

Reynaud, G., 1976. Reproductive capacity and offspring of chickens submitted to a transfer of primordial germ cells during embryonic life. Roux's. Arch. Dev. Biol., 179: 85-110.

Robertson, E.J., 1986. Pluripotential stem cell lines as a route into the mouse germ line. Trends in Genetics, 2: 9-13.

Robertson, I.S., 1961. The influence of turning on the hatchability of hen's eggs. II. The effect of turning frequency on the pattern of mortality, the incidence of malpositions, malformations and dead embryos with no somatic abnormality. J. Agri. Sci., 57: 5769.

Romanoff, A.L., 1960. The Avian Embryo. Macmillan, New York.

Rowlett, K., 1991. Embryo growth and development in culture. in: Avian Incubation. Ed. S.G. Tullet, pp.107-124. ButterworthHeinemann, London.

Rowlett, K. \& K. Simkiss, 1985. The surrogate egg. New Scientist, 1469: 42-44.

Rowlett, K. \& K. Simkiss, 1987. Explanted embryo culture: in vitro and in ovo techniques for domestic fowl. Brit. Poult. Sci., 28: 91-101.

Rowlett, K. \& K. Simkiss, 1989. Respiratory gases and acid-base balance in shell-less avian embryos. J. Exp. Biol., 143: 529-536.

Salter, D.W. \& L.B. Crittenden, 1989. Artificial insertion of a dominant gene for resistance to avian luekosis virus into the germ line of the chicken. Theor. Appl. Genet., 77: 457461.

Salter, D.W., E.J. Smith, S.H. Hughes, S.E. Wright \& L.B. Crittenden, 1987. Transgenic chickens: Insertion of retroviral genes into the chicken germ line. Virology, 157: 236240 .

Salter, D.W., E.J. Smith, S.H. Hughes, S.E. Wright, A.M. Fradly, R.L. Witter \& L.B. Crittenden, 1986. Gene insertion into the chicken germ line by retroviruses. Poult. Sci., 65: 1445-1458.

Sang, H. \& M.M. Perry, 1989. Episomal replication of cloned DNA injected into the fertilised ovum of the hen, Gallus domesticus. Mol. Reprod. Dev., 1: 98-106.

Shoffner, R.N., J.S. Otis, L.A. Snyder \& K.S. Guise, 1990. The improbability of irradiated spermatozoa as gene transfer vectors in chickens. Theor. Appl. Genet., 80: 228-233.

Shuman, R.M., 1990. Genetic engineering. in: Poultry Breeding and Genetics. Ed. R.D. Crawford, pp. 585-598. Elsevier, New York. Shuman, R.M. \& R.N. Shoffner, 1982. Potential genetic modification in the chicken, Gallus 
domestcs. Proc. 2nd. World Cong. Genet. Appl. Livestock Prod. (Madrid), VI: 157163.

Shuman, R.M. \& R.N. Shoffner, 1986. Gene transfer by avian retroviruses. Poult. Sci., 65: 1437-1444.

Simkiss, K., 1991. Primordial germ cells and the scope for genetic manipulation using embryos. in: Avian Incubation. Ed. S.G. Tullett. pp. 125-136. Butterworth-Heinemann, London.

Simkiss, K., K. Rowlett, N. Bumstead \& B.M. Freeman, 1989. Transfer of primordial germ cell DNA between embryos. Protoplasma. 151: 164-166.

Simkiss, K., L. Vick, G. Luke, N. Page \& D. Savva, 1990. Infection of primordial germ cells with defective retrovirus and their transfer to the developing embryo. Proc. 4th World Cong. Genet. Appl. Livestock Prod. (Edinburgh), XVI: 111-114.

Singh, R.P. \& D.B. Meyer, 1967. Primordial germ cells in blood smears from chick embryos. Science, 156: 1503-1504.

Slack, J.M.W., 1983. From Egg to Embryo. Cambridge University Press. Cambridge, England.

Slavkin, H.C., M.D. Slavkin \& P.B. Bringas, Jr., 1980. Mineralization during long-term cultivation of chick embryos in vitro. Proc. Soc. Exp. Boil. Med., 163: 249-257.

Somes, R.G., Jr., 1978. New Linkage groups and revised chromosome map of the domestic fowl. J. Hered. 69: 401-403.

Souza, L.M., T.C. Boone, D. Murdock, K. Langley, J. Wypych, D. Fenton, S. Johnson, P.H. Lai, R. Evertt, R-Y. Hsu \& R. Bossleman, 1984. Application of recombinant DNA technologies to study on chicken growth hormone. J. Exp. Zool., 232: 465-473.

Spratt, N.T., Jr., \& H. Haas, 1960. Integrative mechanisms in development of the early chick blastoderm. I. Regulative potentiality of separeted parts. J. Exp. Zool., 145: 97137.

Spratt, N.T., Jr. \& H. Haas, 1961a. Integrative mechanisms in development of the early chick blastoderm. II. Role of morphogenetic movements and regenerative growth in systematic and topographically disarranged blastoderm. J. Exp. Zool., 147: 57-93.

Spratt, N.T., Jr. \& H. Haas, 1961b. Integrative mechanisms in development of the early chick blastoderm. III. Role of cell population size and growth potentiality in synthetic systems larger than normal. J. Exp. Zool., 147: 271-293.

Stepinska, U. \& B. Olszanska, 1983. Cell multiplication and blastoderm development in relation to egg envelope formation during uterine development of quail (Coturnix coturnix japonica) embryos. J. Exp. Zool., 228: $505-510$.

Swartz, W.J. \& L.V. Domm. 1972. A study on the division of primordial germ cells in the erarly chick embryo. Am. J. Anat., 135: 5170.

Swift, C.H., 1914. Origin and early history of the primordial germ-cells in the chick. Am. J. Anat., 15: 483-516.

Tazawa, H., 1980. Adverse effect of failure to turn the avian egg on the embryo oxygen exchange. Respir. Physiol., 41: 137-142.

Tomita, T., N. Yamamoto, K. Otsuka, M. Ohta \& K. Hirose, 1988. Genetic transformation of egg shell colour in chicken by the use of irradiated sperm. Proc. 18th World's Poult. Cong. (Nagoya), pp. 515-516.

Tuan, R.S., 1980. Calcium transport and related functions in the chorioallantoic membrance of cultured shell-less chick embryos. Dev. Biol. 74: 196-204.

Tullett, S.G. \& D.C. Deeming, 1987. Failure to turn during incubation: Effects on embryo weight, development of the chorioallantois and absorption of albumen. Brit. Poult. Sci., 28: 239-243.

渡辺一雄・井村加奈代, 1983. 卵款外培養によるニワト リ肧の発生一生存率, 形態, 成長速度, 化骨に対す る卵款の意義. 動物学雑誌, 92: 64-72.

Watanabe, M., M. Kinutani, M. Naito, O. Ochi \& Y. Takashima, 1992. Distribution analysis 
of transferred donor cells in avian blastodermal chimeras. Development, 114: in press.

Wentworth, B.C., H. Tsai, J.H. Hallett, D.S. Gonzales \& G. Rajcic-Spasojevic, 1989. Manipulation of avian primodial germ cells and gonadal differentiation. Poult. Sci., 68:
999-1010.

Wiladsen, S.M., 1986. Nuclear transplantation in sheep embryos. Nature, 320: 63-65.

Wilmut, I., M.L. Hooper \& J.P. Simons, 1991. Genetic manupulation of mammals and its application in reproductive biology. J. Reprod. Fert., 92: 245-279. 